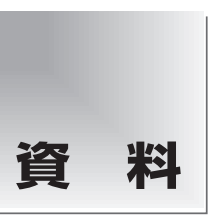

論文受付

2008年10月月論文受付

論文受理

2009年1月30日

Code No. 633

\section{医療用短半減期核種の放射性廃棄物の 適正な管理に向けての文献的考察}

\author{
木田哲生・渡辺 浩1) ・ 山口一郎 ${ }^{2)}$ ・長岡宏明 ${ }^{3)}$ \\ 藤淵俊王 $^{4)} \cdot$ 田中真司 ${ }^{5)} \cdot$ 早川登志雄 ${ }^{6)}$ \\ 滋賀医科大学医学部附属病院放射線部 \\ 1 ) 横浜労災病院中央放射線部 \\ 2) 国立保健医療科学院生活環境部 \\ 3)岩手医科大学附属病院中央放射線部 \\ 4) 茨城県立医療大学保健医療学部放射線技術科学科 \\ 5)東邦大学医療セン夕一大森病院中央放射線部 \\ 6) 社団法人日本画像医療システム工業会
}

\section{緒 言}

国際原子力機関(IAEA) は, Safety Series No.115 (International Basic Safety Standards for Protection against Ionizing Radiation and for the Safety of Radiation Sources : 以下, BSS)「電離放射線に対する防護 および放射線源の安全のための国際基本安全基準」1) を国際放射線防護委員会(ICRP)の1990年勧告 ${ }^{2)}$ に基 づき国連の食糧農業機関(FAO), 国際労働機構 (ILO), 経済協力開発機構内の原子力機関 (OECD/ NEA), 全米保健機関(PAHO) および世界保健機構 (WHO) と共同して1996年に刊行した。わが国におい てもこの国際基準を放射線審議会, 放射線安全規制 検討会 (文部科学省・科学技術学術政策局)において
検討され，平成16年 6 月 2 日に放射線障害防止法へ 国際免除レベル(規制対象下限值)が導入された。こ れを受けて平成17年 6 月 1 日，医療法施行規則の一 部を改正する省令により放射性同位元素の核種ごと の規制対象下限值が導入された。医療での放射性同 位元素の取扱いにも国際基準を導入，現行法令の整 備が進みつつある。

現在，医療機関から排出される放射性廃衰物 $[$ 感染 性医療廃衰物 (オムツ等)を除く]は, 厚生労働大臣の 指定する廃棄業者(社団法人日本アイソトープ協会) に委託廃棄することになっている(医療法施行規則第 30条の14)。この方法によると, 集荷依頼した施設で は, 1〜2 回 / 年の集荷日までその廃呆物を施設内の

\title{
Bibliographic Consideration of Proper Management of Radioactive Waste on Short-lived Period Nuclides That Are Used in Nuclear Medicine
}

\section{Tetsuo Kida, Hiroshi Watanabe,") Ichirou Yamaguchi, ${ }^{2)}$ Hiroaki Nagaoka, ${ }^{3)}$ Toshioh Fujibuchi, ${ }^{4)}$ Shinji Tanaka, ${ }^{5)}$ and Toshio Hayakawa ${ }^{6)}$}

Shiga University of Medical Science Hospital

1 ) Yokohama Rosai Hospital

2) National Institute of Public Health

3) Iwate Medical University Hospital

4) Ibaraki Prefectural University of Health Sciences

5) Toho University Omori Medical Center

6) Japan Industries Association of Radiological Systems

Received October 23, 2008; Revision accepted January 30, 2009; Code No. 633

\section{Summary}

A rational clearance system for medical radioactive waste has not yet been established in Japan. As Europe and USA's ways, the establishment of DIS that medical radioactive waste what are kept in storage room for more than decided period each nuclide except from regulation of radiation's control. The purpose of this report is to clarify the problems with the establishment of DIS in Japan through a literature review of the experience in Europe and the USA and previous research that has been reported in Japan. To establish the DIS system, the radiation control system in nuclear medicine should be rebuilt and put into effect.

Key words: radioactive waste, decay in storage (DIS) 
廃棄保管設備にて保管している。それらの放射活性 は，廃棄時には十分に減衰しているものが多く含まれ るのが現状である。

医療に用いる放射性同位元素は短半減期のものが 多い。これらを含む放射性廃棄物は, 一定期間, 確 実な管理の下で安全を担保し，減衰待ち保管：decay in storage (以下, DIS)することにより放射活性は十分 に小さくなり，そのリスクが無視できるようになる. このため, 短半減期核種を含む放射性廃某物は減衰 させた後, 非放射性の廃棄物とするDISが欧米や韓 国で取り入れられており，実施されている31。わが国 でも今後，法改正が進み，放射性同位元素利用の安 全確保の下，合理的な廃書に移行することが期待さ れる。

\section{1. 目的}

わが国における将来の医療機関から発生する放射 性廃棄物(老朽建造物の解体物を含む)の環境および 医療経済への負荷の軽減のため, 現行の管理・廃棄 の方法が合理的方法に移行されることが望まれる.

そこで，欧米諸国の方法に関するこれまでの研究 成果を集約し，わが国の医療現場にDISを導入するた めに，準備すべき放射線安全対策を明確にし，今後 取り組むべき課題を整理した。

\section{2. 方 法}

平成14 15 年度厚生労働科学研究 医薬安全総合 研究事業(以下, 厚労科研)「医療行為に伴い排出され る放射性廃棄物の適正管理に関する研究」(主任研究 者 日下部きよ子 $)^{3 \sim 6)}$ ，平成17年度同「医療放射線分 野における法令整備等含めた管理体制に関する研究」 (主任研究者 油野民雄 $)^{7,8)}$ では，核医学診療におけ る国際免除レベルの導入のための詳細な研究がなさ れ，その成果が公開されている.

今回，己の二つの厚労科研成果のうち，欧米諸国 における本件に関する現状調査・報告部分を集約し た。ささらに，韓国での医療機関におけるDISの方法に ついての文献を紹介する。最後に，日本アイソトープ 協会に組織されるクリアランスレベル検討委員会報 告9)に提案されているわが国におけるDISを実現する ための条件等を示し，考察した。

\section{3. 結 果}

3-1「医療行為に伴い排出される放射性廃棄物の 適正管理に関する研究」(2004年 3 月) 平成 14 15年度厚生労働科学研究医薬安全総 合研究事業(主任研究者 日下部きよ子)

この研究では, 国際免除レベルの医療法施行規則
への導入に向けての検討として以下の項目について 報告されている。 そのなかで当研究班に関連の深い 下線部分について要約する.

1) BSSの免除レベルの医療法施行規則への取り入れ の検討

2)医療行為に伴い排出される放射性廃棄物の適正管 理に関する検討

2-1) 固体状放射性廃棄物の合理的管理

2-2) 医療行為に伴い排出される液体状放射性廃㶳 物の合理的管理方法の検討

2-3)欧米諸国の法令および実態調査の検討

2-4) (1)医療行為に伴う固体状放射性廃棄物のクリ アランスレベルの検討

(2)わが国の核医学診療に限定してクリアランス レベルが導入された場合の処分ガイドライ ン案の作成

\section{3-1-1 欧米諸国の法令および実態調査の検討}

欧米における医療用放射性廃棄物の取扱いについ て国際勧告書の紹介と要約が示された。紹介された 3 文献は「IAEA BSS No. 115」(1996年),「Council Directive 96/29/EURATOM of 13 May 1996」,

「DRAFT to Safety Guide (Clearance Levels for Solid Materials)」(2000年)である.

そのなかでIAEA BSS No.115(IAEA Safety Series No. 115)についての記述部分を以下に示す.

International Basic Safety Standards for Protection against Ionizing Radiation and for the Safety of Radiation Sources（電離放射線に対する防護および放射線 源の安全のための国際安全基準)

1996年, IAEA Safety Series No. 115「電離放射線に 対する防護および放射線源の安全のための国際安全 基準」が刊行された。このなかに放射性廃棄物の規制 と免除值についての基準および指針(安全指針 RS-G-1.7) が掲載されている9．この基準は，前文， 基本的要件，付録および付則で構成されている．前 文では目的と基礎，基礎となる原理と方針の解説， 基準を運用するための行政上の制度について記述し ている. 基本的要件には基準の目的を履行するため の要件, 付録には基本要件を補足する詳細要件が記 載されている.さらに付則には, 数量的な基準とガイ ダンスレベルおよび用語が解説されている。詳細と関 連情報は文部科学省ホームページに「原子力・放射線 の安全確保」として公開されている10).

このなかで放射性廃棄物に関する記述は付録のIII に記述されている，放射性廃重物の放射能と体積を 最小限にし, IAEA RADWASS刊行物Safety Series No. 111に従って収集，取扱い，処理，コンディショ ニング，輸送，保管および処理の要件を解説してい 
る.

また, 放射性物質の環境への排出については登録 または免許所有者に限定, その責任と要件について も記述している。

\section{3-1-2 諸外国での固体状放射性廃棄物管理の実態 調査結果}

欧州ではすでにIAEAのBSSが規制体系のなかに取 り入れられており, 医療行為から排出される固体状 放射性廃裹物のDISが行われている。ここでは当時 (2003年)のイギリス・ベルギー・ドイツ その他での 実態が調査報告されている.

イギリス：一定期間，一定の放射能量までは廃棄 物が収集保管されること. 短半減期放射性核種の短 期保管と長半減期放射性核種の長期保管に分別す る.これらの処理に関して異なる許可経路を持つ.こ れらの明確な区別の必要性を強調している. 3 施設の 視察の実態は, 施設により多少異なっており, 保管 期間は ${ }^{99 m} \mathrm{Tc}$ ではそれぞれ3・7・10日であった。

${ }^{67} \mathrm{Ga} \cdot{ }^{201} \mathrm{Tl}$ では 2 3 カ月, ${ }^{51} \mathrm{Cr} \cdot{ }^{131} \mathrm{I}$ では 6〜12力月で あった。 そして廃棄時は放射活性を計測後, バック グラウンド值(以下， BG值)に達した場合に一般廃棄 物として処分されていた。廃棄物の外袋には核種・ 活性等が記載された廃棄物移送書類が添付されてい た ${ }^{3}$.

ベルギー：半減期が180日未満の核種については半 減期の10倍の期間保管し, 計測後に一般の廃棄物と して処分されていた。 陽電子放出核種 (半減期が 2 時 間以内)については翌日までのDIS期間で処分されて いる.

半減期の長さによって I V 群に分類されている. I 群は半減期が 6 時間以内の核種, II群は80時間以 内, III群は70日以内の核種で保管期間は, それぞれ 3 日, 1 月, 2 年である. 半減期が 0.5 年を超えるもの はV群として廃棄委託されていだ2.

ドイッ: 半減期が100日以内のものは半減期の 10 倍 の期間保管し一般廃棄物として処分していた。100日 以上のものに関しては廃裹委託での処分であった ${ }^{3)}$.

その他文献等で調查した諸外国の現状として報告 されている。

デンマーク：廃棄物の容器に収納し, 容器に表面 線量率が $5 \mu \mathrm{Sv} / \mathrm{h}$ 未満であれば一般廃棄物として処分 が可能である4).

フランス：半減期71日未満の核種は一定期間減衰 保管, 測定してBGレベルを確認し, 記録を残して一 般廃棄物として処分を行う ${ }^{4}$.

ポルトガル：固体状放射性廃棄物は容器の表面線 量率がBGレベル $(0.1 \sim 0.2 \mu \mathrm{Sv} / \mathrm{h})$ となるまで減衰保管 した後, 一般廃棄物として処分が可能である ${ }^{4)}$.
アメリカ：物理的半減期が120日未満の核種は減衰 待ち保管してもよい(少なくとも10半減期). 放射線測 定器にてBGレベルと区別つかないことを確認し, 放 射線ラベルを取り除いて，一般廃棄する。測定の記 録は 3 年間保管する4).

以上のように国により細部に違いはあるが基本的に は一定期間のDISの後, 表面線量率がBGレベルであ ることを確認した後に一般廃棄物として廃棄する方 式が採用されている.

\section{3-1-3 医療行為に伴う固体状放射性廃棄物のクリ アランスレベルの検討}

欧米諸国では，核医学診療に伴う固体状放射性廃 棄物は使用する放射性同位元素が短半減期かつ種類 も限定されており，使用目的が明確に規定されてい る.ささらに, 放射線管理システムが整備されているこ と等の条件の下で放射能が一定レベルに減衰した廃 裹物は一定の行為基準により一般廃棄物として処分 することが可能である。本邦に打いても医療に限定し て放射線学的評価に基づいた安全な管理と廃棄方法 を実行することにより，適切に廃棄物処分を行うと いったクリアランス概念も検討されている。 これは廃 棄ごと, 核種ごとに放射能濃度を測定するのではな く, DISで安全を担保し, 線量率測定により確認とそ の品質を保証するものである，一方，この検討では， わが国に扔けるクリアランスレベルを提案している. そのクリアランスレベルは, 日本で用いられる25核種 が対象である。計算に用いられるパラメータのうち, 外部被ばくの線量係数はこの研究班で求められたも のを, 吸入・摂取ではCouncil Directive 96/29/EURATOM の值が採用されている. 皮膚の線量係数はRP-122か ら引用された. クリアランスレベルの算出は包括シナ リオで示される外部被ばく・吸入・経口・皮膚污染の 計算式をもとに金属，コンクリート，すべての固体状 物質の線量係数とパラメー夕を用いている. 従事者 や一般公衆を対象として設定したシナリオにて放射 線リスクを評価し，その安全性を担保した日本でのク リアランスレベル案を作成, 提案している.

3-2「医療放射線分野における法令整備等含めた管 理体制に関する研究」(2006年 3 月) 平成16 17 年度厚生労働科学研究医療安全・医療技術 評価総合研究 (主任研究者 油野民雄)

この研究は医療放射線分野に打ける法令整備等含 めた管理体制に関する研究として計画され, 二本の 柱(研究中項目)にて進められた。一つは医療法への 国際免除レベルの取り入れに関する研究として, 医 療機関への影響や取り入れに関する研究と医療法施 行規則の法整備についてである。もう一つは医療放 


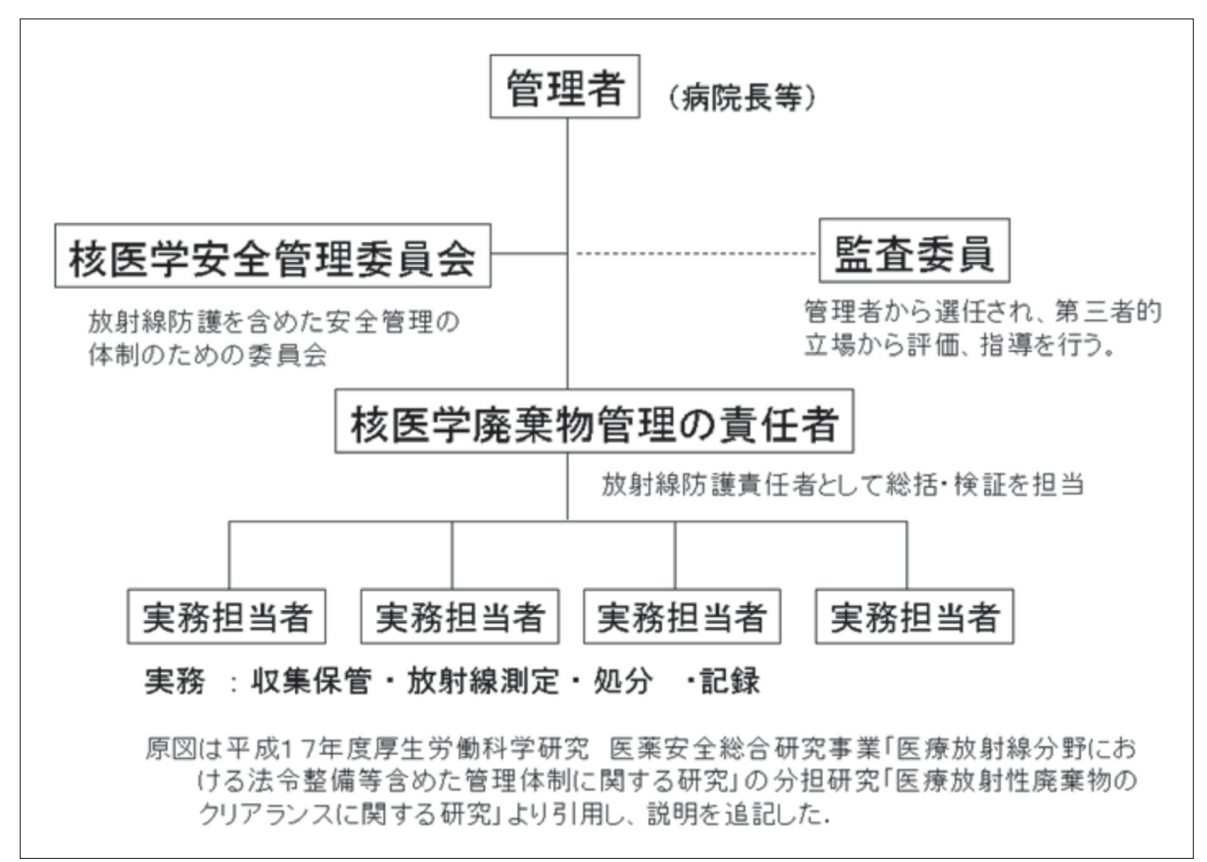

Fig. 1 Example of a radiation safety control system.

射線の安全管理体制の制度化に関する研究として, 医療放射線の規制管理に対する国際動向に関する研 究と医療放射性廃菓物のクリアランスに関する研究 である。

研究項目は以下のとおりである.

このなかで関連の深い下線部分について要約する。

1)医療法への国際免除レベル取り入れ等に関する研 究

1-1) 国際免除レベル取り入れに伴う医療機関への 影響に関する研究

1-2）国際免除レベルの医療法取り入れに付随する 関連事項に関する研究

1-3）医療機関に扮ける適切な放射線防護および関 係する制度についての研究

2) 医療放射線の安全管理体制の制度化に関する研究

2-1) 医療放射線の規制管理に対する国際動向の把 握に関する研究

2-2）中長期的に展望する医療放射線の安全規制に 関する研究

3) 医療放射性廃棄物のクリアランスに関する研究

4)「医療放射線分野に打ける法令整備等含めた管理 体制」シンポジウム開催

\section{3-2-1 医療放射性廃棄物のクリアランスに関する 研究}

2004年の放射線障害防止法改正に伴い，原子炉 . 研究機関などに導入されたクリアランスレベルによる 放射性廃棄物の処分方法を医療現場にそのまま適応 させることは困難であった，その後，現在までその情
勢は変わっていない，前述のように医療に用いられる 放射性同位元素の特徵と使用状況では確実な管理下 にあれば，必ずしも原子炉等と同じ方法でなくとも放 射線安全は担保されると考える。

この研究では医療に打ける放射線安全管理の重要 性を周知させることを一目的とした教育的なアンケー 卜調査を行い，現場での認識の向上を図った。

そのなかで各施設に放射線安全管理委員会を設置 し，それを中心に安全管理体制を構築，機能してい くことでDIS等新しい合理的な廃棄方法が実現できる としている，さらにそのガイドライン案とマニュアル 案が提案された。そこでは，(1) 安全管理体制と保管 管理・廃棄方法の客観的評価, (2) 分別の重要性, (3) 安全取扱い方法, (4) 記録の義務化等について記載さ れている。ここで提案されている放射線管理に関す る組織図をFig. 1に示す。

\section{3-3 韓国における現状}

渡辺らは2008年 5 月に訪韓, 3 病院の放射性廃裹 物処分の実際を視察し韓国における現状を報告して いる ${ }^{11)}$.

韓国では2001年に科学技術部(日本の文部科学省に 相当. 2008年 2 月に教育科学技術部と改名) は「放射 性廃棄物の自己処分に関する規定」として原子力法施 行令および施行規則の改正を行った。「自己処分」と は各事業所でのDISを指す，その規定のなかで許容基 準と核種別濃度としてクリアランスレベルを規定して いる。 その濃度基準は半減期が 100 日以下の $\beta \cdot \gamma$ 線放 
出核種は基本的には $100 \mathrm{~Bq} / \mathrm{g}$ とており，これは国際 的に用いられているIAEA RS-G-1.7とほぼ同值である。

自己処分する放射性廃衰物は処分制限值未満であ ること, 処分時点でその他の基準を満足していなけ ればならない. その基準として,

(1) 発生廃棄物の核種の種類

(2) 廃棄物の保管期間とその評価方法

(3) 廃棄物の分離貯蔵の方法

(4) 処分の記録内容と様式

(5) 廃棄物の放射線 / 能の測定方法

(6) 処分の方法

である，施設はこの基準を満たしていることを行政 に対し手続きを行い，これを履行しなければならない.

廃棄を行う際その計画書があらかじめ必要であ り, 記載内容として以下のものが必要とされている.

(1) 廃棄物の発生源 - 種類 - 数量 - 表面線量率

(2) 廃肓物に含まれる放射性物質の種類 - 数量 ·濃 度

(3) 処分に付随して発生する廃棄物の量

(4) 規定に対する処分手続き

その他「放射性廃棄物の自体処分の手続き標準案」 としてマニュアル案が提供されている.

\section{3-4 RI施設のクリアランス検討委員会報告書の 概要}

文部科学省放射線安全規制検討会の要請を受けて 日本アイソトープ協会は, RI使用者の提案・要望を 参考にとりまとめることを目的とした「RI使用施設に おけるクリアランス検討委員会」を組織した。その報 告 ${ }^{12)}$ のなかで. 日本アイソトープ協会が平成 11 年 15 年までの期間に集荷した放射性廃棄物の調査では, 障害防止法に規制される廃䢂物のうち $66 \%$ は RS-G-1.70クリアランスレベルに達しているクリアラ ンス相当物であった。 また，医療関連法に規制される 廃衰物では，90.5\%がクリアランス相当物であったと 報告している。クリアランス検認制度について原子炉 施設・RI使用施設での概念さらにはDISによるクリア ランスレベルの検認制度が解説されている．DISによ るクリアランスレベル検認制度におけるRI廃棄物のク リアランスまでの流れをFig. 2に示す。この制度が安 全で合理的方法であると社会に定着するまで導入施 設では，施設の管理保管方法について国または第三 者機関の確認が必要であるとしている。ただし現行 の廃棄方法がこの方法に置換されるのではなく各施 設での採否選択が可能である。この制度の導入に必 要な技術とその品質保証が不可欠であり, その実務 性と経済性を考慮して施設での導入を検討すべきで あるとしている。

\section{4. 考 察}

わが国における放射性廃棄物の廃棄の方法は現行 法令の下, 厚生労働省令で指定委託された業者にて 医療機関から持ち出されている。文献12)では，医療 関連法に規制される事業所(医療機関)からは排出さ れる集荷廃棄物の $90 \%$ 以上がクリアランス相当物で あるとしていることからも現行廃衰方法が規制緩和 側へ改正されることが望まれる。現実には 1 回 / 年の 集荷までの保管期間は，それらに含まれる放射性同 位元素の半減期に比較して非常に長く, 廃衰保管室 で十分に減衰されることになる。集荷時のその廃萧 物の放射活性は低く, 一般環境へのリスクが極めて 低いものがほとんどであることを示している.

使用する製剤のクリアランスレベル到達点を試算 した。 ${ }^{99 \mathrm{~m}} \mathrm{Tc}$ 製剤555MBqをそのまま廃衰したとして， それがRS-G-1.7に示されるクリアランスレベル100Bq/g に到達する時間は4.8日である(重量を $8.8 \mathrm{~g}$ として算 出)。同様に ${ }^{123} \mathrm{I}$ 製剤 $(167 \mathrm{MBq} / 8.6 \mathrm{~g})$ では9.5日， ${ }^{201} \mathrm{~T} 1$ 製 剂 $(111 \mathrm{MBq} / 8.8 \mathrm{~g})$ では52日である。この期間，各施設 で適切な場所で保管すれば一般廃衰物あるいは産業

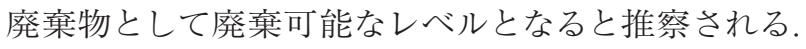
環境への影響が小さいことなどを考慮すると，われ われが現在行っている廃棄方法は過剰管理である.

今回, 調査した研究の成果からも諸外国が行うDIS などの合理的方法に転換することが望ましいと考え る.

欧米および韓国の方式では，管理期間，方法，対 象に対する安全性を考慮した管理体制と専属の責任 者による管理下でDISが行われている。日本の医療施 設における放射性廃棄物を含めた放射線管理組織の 組織率は低く，管理体制がいまだ不十分であること がこれまでの調査から判断される.

Fig. 1に示される管理組織例は, 欧米のDIS導入国 での方法を参考に提案されている。わが国では，長 年の委託廃衰制度により医療機関での放射性廃呆物 の自己管理意識は決して高くない. 平成13年 3 月の 医薬発第188号厚生労働省医薬局長通知を受けて, 各施設で「放射性医薬品を投与された患者のオムツ等 の管理の必要が生じた。しかし, 文献6)の「固体状放 射性廃肓物の合理的管理」のアンケート調査の報告で もその管理実態は十分ではないと判断される。今後 の自己管理意識の向上・定着は必須条件で，機能す る管理組織の構築が重要と考える。そこで核医学安 全管理委員会や放射性廃棄物の管理責任者の責務は 重大であり, その存在はDIS検認クリアランスに不可 欠な条件事項になる。

監査委員は，部外者が選任されるとしている．DIS 検認クリアランスのための一定の施設基準や要件を 


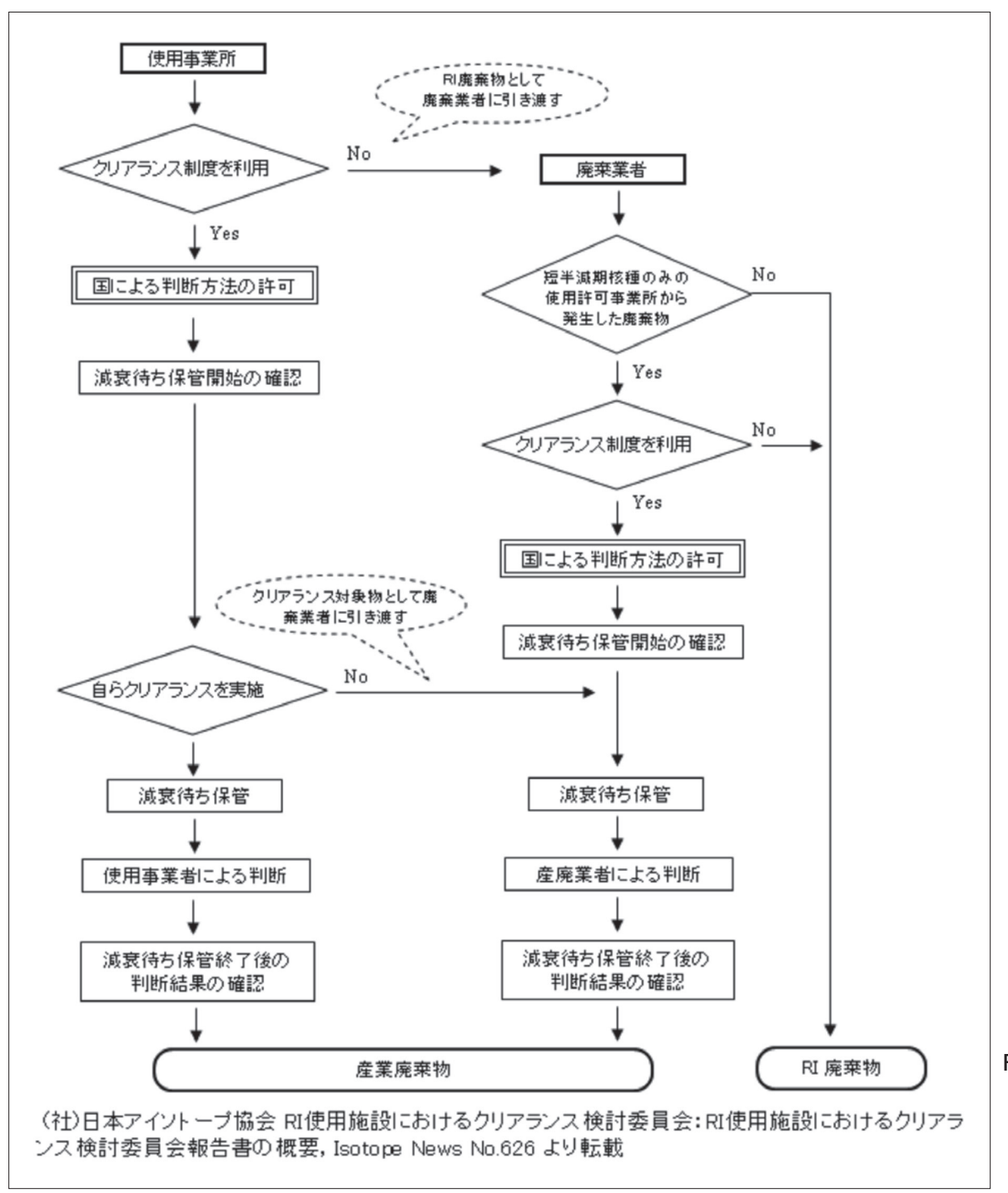

Fig. 2 Flow chart of radioactive (RI) waste clearance using the national system of checking decay in storage (DIS) radioisotope clearance.

公正かつ客観的な評価を行うことが目的とされる.

RI施設のクリアランス検討委員会では，導入時に は, 制度の定着と減衰待ちクリアランスの社会的信 頼を得るため, 国による介入・指導・チェックが必要 であるとしている。これは過渡期においては必要な手 続きであると考える.

今後の組織やシステムの条件などの動向は流動的 であり大いに注目されるが，保管から廃衰の一連に は実務的な安全性と確実性が高い方策が必要であ り，関係者への教育・周知等も必要と考える.

経費的な側面では，DISによる放射性廃棄物処分 を実現するには組織や設備備品への経費が必要とな るが，結果として経済的負担も軽減されることを期待 するものである12).

\section{5. 結 語}

医療行為により排出される放射性廃棄物 (固体と液 体)の合理的な処分方法の可能性と方向性について現
在までに進められてきた二つの厚労科研，韓国にお ける実務方法の報告書，日本アイソトープ協会のRI 施設のクリアランス検討委員会報告を調査した。厚 労科研や韓国のDIS実情の調査では，わが国への導 入の際の考慮すべき点, 環境安全性の評価等が行わ れていた。 RI施設のクリアランス検討委員会報告書 の概要には，わが国の医療機関を対象とした減衰待 ちクリアランス検認制度の解説とその導入の必要条 件が示された。

放射性廃亲物の処分方法の見直しは，医療用放射 性同位元素関連の廃棄物だけでなく, 装置や施設更 新時の処分方法や費用と深く関連する.

制度導入には，放射線管理体制の確立と経済的側 面も併せて考慮される。

今後の関連法の改正と合理的廃妄方法を実現的な ものとするための予備知識としていただきたい.

減衰待ちクリアランス検認制度は, 放射性医薬品 に微量含有の異核種や長半減期娘核種も考慮して減 
衰期間と保管方法の適切性を保証し，放射性同位元 素に污染されたものを非放射性廃棄物とするもので ある。原子力分野では代表核種を対象に放射能濃度 を測定, それが一定濃度以下の污染であることを事 業者が検認しクリアランスする制度が導入されてお り，それとは手順が異なる。医療で使用する核種が 短半減期核種であること, 使用核種の種類・数量 · 用途が限定されていることなどの特徵から提案され たものである。
なお，本研究は，本学会学術研究「放射性廃棄物 等管理と処分に関する研究班」の一環として行った。

\section{謝 辞}

本研究へ図表資料の引用および転載を快く許諾, 本研究への活用をご指導いただきました東京女子医 科大学病院放射線科 日下部きよ子教授，(社)日本 アイソトープ協会およびIsotope News編集委員会に深 く感謝致します.

\section{参考文献}

1) IAEA. Safety Series No.115. International Basic Safety Standards for Protection against Ionizing Radiation and for the Safety of Radiation Sources. Vienna, 1996.

2）日本アイソトープ協会 訳. 国際放射線防護委員会の1990 年勧告(ICRP Publ.60)。東京：丸善, 1991 .

3) 戸川貴史, 橋本 順, 百瀬 満. 欧米諸外国の法令研究 及び実態調查. 平成 15 年度厚生労働科学研究費補助金報 告書 (医薬安全総合研究事業)「医療行為に伴い排出される 放射性廃棄物の適正管理に関する研究」総括・分担研究 報告書. $2004 ： 145-154$.

4) 木下富士美, 細野 眞. 医療行為に伴う固体状放射性廃 棄物のクリアランスレベルの算出, 平成 15 年度厚生労働科 学研究費補助金報告書 (医薬安全総合研究事業)「医療行 為に伴い排出される放射性廃棄物の適正管理に関する研 究」. $2004: 180-182$.

5）日下部きよ子．「医療行為に伴い排出される放射性廃棄物 の適正管理に関する研究」. 平成14年度厚生労働科学研究 費補助金(医薬安全総合研究事業) 総括- 分担研究報告 書. 2003 .

6）日下部きよ子。「医療行為に伴い排出される放射性廃棄物 の適正管理に関する研究」. 平成14～15年度厚生労働科学 研究費補助金 (医薬安全総合研究事業) 総括 - 総合 - 分担 研究報告書. 2004

7）日下部きよ子．「医療放射性廃棄物のクリアランスに関す
る研究」. 平成16年度厚生労働科学研究費補助金(医療技 術評価総合研究事業)。「医療放射線分野における法令整 備等含めた管理体制に関する研究」総括・分担研究報告 書. 2005 .

8）日下部きよ子。「医療放射性廃棄物のクリアランスに関す る研究」, 平成17年度厚生労働科学研究費補助金(医療技 術評価総合研究事業)。「医療放射線分野における法令整 備等含めた管理体制に関する研究」総括・分担研究報告 書. 2006.

9）経済産業省．IAEA安全指針RS-G-1.7「規制除外，規制免 除及びクリアランスの概念の適用」の概要.

http://www.meti.go.jp/committee/materials/downloadfiles/ g41213c11j.pdf

10）文部科学省「国際免除レベルの法令への取り入れの基本的 考え方について」

http://www.anzenkakuho.mext.go.jp/anzenkakuho/index. html

11）渡辺 浩, 長岡宏明, 山口一郎, 他. 韓国に抢ける医療 利用に伴う放射性廃棄物の管理と処分の実施状況調查. 核医技 2009 .

12）(社)日本アイソトープ協会：RI使用施設におけるクリアラ ンス検討委員会. RI使用施設におけるクリアランス検討 委員会報告書の概要. Isotope News $2006 ; 626 ： 9-14$. 